\title{
Christian Nationalism and Political Violence: Victimhood, Racial Identity, Conspiracy, and Support for the Capitol Attacks
}

\author{
Miles T. Armaly ${ }^{1}$ D $\cdot$ David T. Buckley ${ }^{2} \cdot$ Adam M. Enders $^{2}$
}

Accepted: 6 November 2021 / Published online: 4 January 2022

(C) The Author(s), under exclusive licence to Springer Science+Business Media, LLC, part of Springer Nature 2021

\begin{abstract}
What explains popular support for political violence in the contemporary United States, particularly the anti-institutional mob that attacked the U.S. Capitol in January 2021 ? Recent scholarship gives reason to suspect that a constellation of beliefs known as "Christian nationalism" may be associated with support for such violence. We build on this work, arguing that religious ideologies like Christian nationalism should be associated with support for violence, conditional on several individual characteristics that can be inflamed by elite cues. We turn to three such factors long-studied by scholars of political violence: perceived victimhood, reinforcing racial and religious identities, and support for conspiratorial information sources. Each can be exacerbated by elite cues, thus translating individual beliefs in Christian nationalism into support for political violence. We test this approach with original survey data collected in the wake of the Capitol attacks. We find that all the identified factors are positively related to each other and support for the Capitol riot; moreover, the relationship between Christian nationalism and support for political violence is sharply conditioned by white identity, perceived victimhood, and support for the QAnon movement. These results suggest that religion's role in contemporary right-wing violence is embedded with non-religious factors that deserve further scholarly attention in making sense of support for political violence.
\end{abstract}

Keywords Christian nationalism · Victimhood - White identity · Conspiracy theory · Political violence $\cdot$ QAnon

Miles T. Armaly

mtarmaly@olemiss.edu

David T. Buckley

dtbuck02@louisville.edu

Adam M. Enders

adam.enders@louisville.edu

1 Department of Political Science, University of Mississippi, Oxford, MS, USA

2 Department of Political Science, University of Louisville, Louisville, USA 


\section{Introduction}

In January 2021, a rally organized to protest the results of the 2020 presidential election escalated into the violent takeover of the United States Capitol building. While rioters utilized a wide variety of symbols and slogans in the planning and execution of those attacks, religious motifs were a regular fixture of what one reporter labeled "a Christian insurrection." Religion's appearance that afternoon was not unexpected, as prominent religious supporters of the Trump Administration framed electoral defeat as an anti-religious conspiracy even before the November election. ${ }^{2}$ In the days before the Capitol violence, supporters launched a "Jericho March" against alleged electoral fraud, intended to imitate the biblical siege of Jericho by Israelite forces. $^{3}$

Analytically, the role of religion in the 2021 Capitol attacks is the latest manifestation of a concept that has attracted significant recent attention in the social sciences: Christian nationalism. Leading scholars define Christian nationalism as a "pervasive set of beliefs and ideals that merge American and Christian group memberships," and have presented convincing evidence of its links to a spectrum of conservative politicians and policy positions, notably the election of President Donald Trump (Whitehead et al., 2018a, 2018b, 148; Perry, Whitehead and Grubbs 2021). While this body of work predates the 2021 violence, it comes with obvious implications for understanding the sources of support for the riots. However, significant theoretical work remains to be done if we are to explain the factors that may tie Christian nationalism, essentially a set of political-theological beliefs, to support for or participation in political violence.

We advance a two-part theory linking Christian nationalism to political violence, particularly the January 2021 Capitol attacks. First, we expect an independent link between Christian nationalism and support for political violence, including the right-wing violence in the wake of Trump's electoral defeat. Second, because robust research on religion and violence suggests that "extreme" religious beliefs are incomplete explanations of support for or participation in political violence, we argue that the effect of an ideology like Christian nationalism is likely to be conditioned by other individual characteristics that scholars have identified as particularly susceptible to elite cues. We focus on three such characteristics because of their links to threat perception and boundary construction: perceived victimhood, reinforcing racial and religious identity, and immersion in conspiratorial information sources. More succinctly, we argue that Christian nationalism is strongly related

\footnotetext{
1 Emma Green, "A Christian Insurrection," The Atlantic, January 8, 2021. Available at: https://www. theatlantic.com/politics/archive/2021/01/evangelicals-catholics-jericho-march-capitol/617591/

2 Peter Manseau, "Some Capitol rioters believed they answered God's call, not just Trump's," Washington Post, February 11, 2021. Available at:

https://www.washingtonpost.com/outlook/2021/02/11/christian-religion-insurrection-capitol-trump/

3 Bob Smietana, "Jericho March Returns to DC to Pray for a Trump Miracle," Religion News Service, January 5, 2021. Available at:

https://www.christianitytoday.com/news/2021/january/jericho-march-dc-election-overturn-trump-bidencongress.html
} 
to support for specific and abstract political violence on its own, but will be most potent when combined with certain individual-level characteristics that political elites have a hand in cueing.

This theoretical approach, contextualizing the study of Christian nationalism within the broader study of religion and political violence, offers one attempt at "integrat[ing] Christian nationalism into conceptions of politicized religion" (Lewis, 2021, 115). The 2021 Capitol attacks were unique in American history, but links between religion, extremism, and violence are well-trodden analytic ground in the social sciences, with empirical work on the United States and a host of global cases. Drawing on such work suggests links between essentially a bottom-up ideology like Christian nationalism and top-down elite discourse that, when combined, may result in violence. Specifying such channels represents theoretical progress and may help to avoid mistakes of earlier generations in the study of religion and political violence, which at times overstated religious ideological influences in the search for "moderate" religious beliefs that would alone reduce security threats. ${ }^{4}$

\section{Christian Nationalism: Tying American Religion to Political Violence}

The set of beliefs characterized as "Christian nationalism" blends a religious understanding of America's origins with nearly "apocalyptic" views on future threats to that Christian heritage (Gorski, 2019, 165). While ties between religion and American nationalism are not new (Bellah, 1992), recent scholarship has focused on a more particular operationalization of "a unique and independent ideology" centered on "a symbolic defense of the United States' perceived Christian heritage" (Whitehead et al., 2018a, 2018b, 147). Christian nationalism not only affirms a uniquely American Christian history, but also highlights the alleged danger to that heritage from rapid demographic, legal, and political change. Conceptually and empirically, Christian nationalism "is not synonymous with or reducible to" dimensions of religiosity, such as levels of religious attendance, or elements of political ideology, like partisanship (Ibid, 153). ${ }^{5}$ Christian nationalism, as operationalized in this recent literature, resonates with the broader concept of "religious nationalism" (Soper \& Fetzer, 2018) in which a "fusion" (Grzymala-Busse 2015, 7) develops between religion and national identity. Fox (2004) uses cross-national data to argue that religious nationalism is increasingly associated with political violence, while also arguing that religious nationalism's influence should be thought of as contingent on broader

\footnotetext{
${ }^{4}$ For an early example of thinktank research emphasizing "moderate" ideology, see "Building Moderate Muslim Networks," RAND Corporation, 2007. Available at: https://www.rand.org/content/dam/ rand/pubs/monographs/2007/RAND_MG574.pdf. For an overview of empirical shortcomings in this approach, see "Why Countering Violent Extremism Programs Are Bad Policy," Brennan Center for Justice, September 9, 2019. Available at: https://www.brennancenter.org/our-work/research-reports/whycountering-violent-extremism-programs-are-bad-policy

5 This is not to rule out links between Christian nationalism and measures of religious affiliation or behavior. Indeed, we present correlations between Christian nationalism and common measures of religious affiliation and service attendance in the appendix.
} 
political dynamics in a given country. Soper and Fetzer (2018), Gorski (2017), and others highlight that, while Christian nationalism has been a regular historical feature of the American landscape, it has generally been a minority position in contrast with the more dominant, pluralistic concept of "American civil religion."6

This conceptualization of Christian nationalism has generated a flurry of recent research linking this political-religious ideology to attitudinal and behavioral outcomes, especially those tied to Donald Trump's presidency. In a series of projects, Whitehead, Perry and coauthors have demonstrated an independent relationship between Christian nationalism and Trump support, even accounting for alternative explanations of Trumpism such as racism and socioeconomic status (Baker et al., 2020; Whitehead \& Perry, 2020). Gorski (2019, 165) argues that "Trumpism, then, is a reactionary and secularized version of white Christian nationalism." Similar empirical work has extended Christian nationalism beyond electoral contexts, for example tolerance of racism (Davis \& Perry, 2020), anti-immigrant attitudes (McDaniel et al., 2011), anti-Islamic sentiment (Shortle \& Gaddie, 2015), attitudes towards same-sex unions (Whitehead \& Perry, 2015), and even responses to COVID-19 (Perry et al., 2020a, 2020b). While not tied to extrajudicial political violence, Christian nationalism has been linked to tolerance of police violence against African-Americans (Perry et al., 2019), as well as opposition to gun control regulations (Whitehead et al., 2018a, 2018b).

Over roughly the same time period, scholars have paid closer attention to the impact of conspiracism on public opinion, including its links to religious symbolism and imagery. The QAnon movement is particularly relevant given both the visible presence of QAnon supporters at the Capitol riot and the religious imagery deeply embedded within QAnon canon. QAnon is a conspiracy movement that began on the 4chan imageboard in 2017 when an anonymous poster using the pseudonym "Q" began communicating cryptic messages said to convey the details of Donald Trump's secret battle with the "deep state." Although this movement is typically explained through political affiliation with Donald Trump, QAnon lore-which shares many similarities with claims made during the "Satanic panic" of the 1980s - is littered with eschatological "end times" and Manichean imagery regarding a final war (called "the Storm") between a corrupt, evil elite and a virtuous, good people. The linkage between religion, conspiracy thinking, and extremist political movements is nothing new (Barkun, 1997, 2017). Although less well developed in scholarly literature, initial evidence seems to indicate that Christian nationalism may be tied to support for the QAnon movement and related conspiracy theories. ${ }^{7}$

\footnotetext{
${ }^{6}$ While civil religion is commonly defined as non-dependent on Christian identification, Jacobs and Theiss-Morse (2013) show that Christians commonly connect Christianity to American national identity.

7 Paul Djupe and Jacob Dennen, "Christian nationalists and QAnon followers tend to be anti-Semitic. That was seen in the Capitol attack." Washington Post-Monkey Cage, January 26, 2021. Available at: https://www.washingtonpost.com/politics/2021/01/26/christian-nationalists-qanon-followers-tend-beanti-semitic-that-was-visible-capitol-attack/

Paul Djupe and Ryan Bruge, "A Conspiracy at the Heart of It: Religion and Q," Religion in Public, November 6, 2020. Available at: https://religioninpublic.blog/2020/11/06/a-conspiracy-at-the-heart-of-itreligion-and-q/
} 
While links to protesting alleged election fraud have not appeared in this growing body of literature, there is ample evidence in reportage from before, during, and after the Capitol riots to motivate an expectation that Christian nationalism played a part in this novel form of American political violence. Several of Trump's most prominent Christian supporters framed his efforts to undermine the 2020 election results in religious terms. For example, shortly after the election, prominent televangelist Paula White declared, "demonic confederacies...are attempting to steal the election from Trump." ${ }^{8}$ This elite rhetoric translated into social organization through the Jericho March, an initiative led by Trump loyalists that held a series of prayer meetings aimed at overturning the election, "modeled on a biblical battle in which the Israelites marched around the city of Jericho until its walls crumbled." A Catholic archbishop described attendees as, "the praying army that walks around the walls of lies and betrayal in order to bring them down." 10 Members of the Proud Boys knelt in prayer to Jesus for "reformation and revival" in the United States. ${ }^{11}$ Protest signs linked conspiratorial allegations of voter fraud to biblical passages, and protester interviews featured references to the end times and scriptural prophecy about Trump's election. ${ }^{12}$ Rioters brandished bibles, invoked Jesus' name in chants, and carried placards stating "Jesus is My Savior, Trump is My President."13 Attackers in the Senate chamber prayed "thank you heavenly father for gracing us with this opportunity."14

Interestingly, after the Capitol attacks, a series of faith-leaders and policy analysts have agreed with protesters that Christian nationalism was at the root of that day's events. Several hundred prominent evangelical clergy members launched the "Say 'No' to Christian Nationalism" campaign to "recognize and condemn the role Christian Nationalism played in the violent, racist, anti-American insurrection at the United States Capitol on January 6." 15 The evangelical magazine Christianity Today adopted a similar framing in "offer[ing] advice to church leaders trying

\footnotetext{
${ }^{8}$ Wyatte Grantham-Philips, "Pastor Paula White calls on angels from Africa and South America to bring Trump victory," USA Today, November 5, 2020. Available at: https://www.usatoday.com/story/news/ nation/2020/11/05/paula-white-trumps-spiritual-adviser-african-south-american-angels/6173576002/

9 Elizabeth Dias and Ruth Graham, "How White Evangelical Christians Fused With Trump Extremism," New York Times, Jaunary 11, 2021. Available at: https://www.nytimes.com/2021/01/11/us/how-whiteevangelical-christians-fused-with-trump-extremism.html

10 Paul Moses, "The renegade Catholic clerics who shamefully backed Trump's Big Lie," CNN.com, January 19, 2021. Available at: https://www.cnn.com/2021/01/19/opinions/catholic-clerics-who-backedtrump-big-lie-moses/index.html

${ }^{11}$ Dias and Graham, "How White Evangelical Christians Fused.".

12 Jeffrey Goldberg, "Mass Delusion in America," The Atlantic, January 6, 2021. Available at: https:// www.theatlantic.com/politics/archive/2021/01/among-insurrectionists/617580/. Green, "A Christian Insurrection.".

${ }^{13}$ Matthew Avery Sutton, "The Capitol Riot Revealed the Darkest Nightmares of White Evangelical America," The New Republic, January 14, 2021. Available at: https://newrepublic.com/article/160922/ capitol-riot-revealed-darkest-nightmares-white-evangelical-america

${ }^{14}$ Luke Mogelson, "A Reporter's Video from Inside the Capitol Siege," The New Yorker, January 6, 2021. Available at: https://www.newyorker.com/video/watch/a-reporters-footage-from-inside-the-capitolsiege

15 https://saynotochristiannationalism.org/
} 
to deradicalize members of their own community." ${ }^{16}$ Deradicalization raises the specter of ideological approaches to countering terrorism developed largely with Muslim communities in mind. Two security analysts explicitly draw this link in arguing, "Programs designed to reform violent jihadis could help tackle the spread of QAnon and other conspiracy theories in evangelical communities."17

\section{Conditioning Christian Nationalism's Effects: Theories of Religion, Ideology, and Violence}

Extant research and journalistic evidence from the day of the attack justify a baseline expectation that Christian nationalism would be tied to support for political violence at the Capitol on January 6. However, analysts linking this basic expectation to a longer history of ideological approaches to the study of radicalization and political violence should be cautious. As the Brennan Center for Justice summarizes, "The key assumption of radicalization theory is that individuals who adopt 'extremist' ideologies start down a conveyor belt that leads inexorably toward becoming a terrorist. While this proposition may have some intuitive appeal, decades of empirical research disproves it." ${ }^{\prime 18}$ We briefly review the evidence that purely ideological approaches to the study of religion and violence have significant limitations, and then use extant literature to develop more nuanced expectations tying the influence of Christian nationalist ideology to individual characteristics that are both connected to Christian nationalism, and susceptible to inflammation vis-a-vis elite cues. In sum, we argue that perceived victimhood, reinforcing racial and religious identity, and immersion in conspiratorial information networks are each likely to increase individual exposure and/or receptivity to elite rhetoric cueing these identities and views of the world, which in turn strengthen the link between Christian nationalism and violence.

While focus on Christian nationalism and political violence has taken on new urgency after the Capitol riots, the search for ideological origins of violence has a long and contentious history, especially in the study of religion and terrorism. Early studies of religious terrorism highlighted the "theological demand or imperative" at the root of such violence (Hoffman, 1993, 2), its roots in "divine instructions transmitted long ago or in interpretations of precedents from founding periods" (Rapoport, 1984, 674), and the "cosmic struggle" motivating participants (Juergensmeyer, 2017). Prominent post-9/11 policy reports applied such theoretical claims to Muslim communities, where, supposedly, "the struggle underway...is essentially a war

\footnotetext{
16 Morgan Lee, "Christian nationalism is worse than you think," Christianity Today, January 13, 2021. Available at: https://www.christianitytoday.com/ct/podcasts/quick-to-listen/christian-nationalism-capitolriots-trump-podcast.html

17 Melissa Graves and Mohammad Fraser-Rahim, "The U.S. Needs Deradicalization-for Christian Extremists," Foreign Policy, March 23, 2021. Available at: https://foreignpolicy.com/2021/03/23/usaneeds-qanon-deradicalization-christian-extremists/

18 "Why Countering Violent Extremism Programs Are Bad Policy.”.
} 
of ideas"19 requiring "robust response" to "an ideological threat." ${ }^{20}$ The Obama Administration's "Joint Strategy on Countering Violent Extremism" asserted "commonality in the ideology and narratives employed by terrorist groups," ${ }^{21}$ and the Trump Administration doubled down on "combat[ing] the violent, extreme, and twisted ideologies that purport to justify the murder of innocent victims." ${ }^{22}$

Extensive research on religion and violence, however, raises significant questions about the sufficiency of ideological explanations. At a basic level, a multitude of studies have shown no consistent evidence of links between religiosity and support for terrorist violence in several comparative settings (Fair \& Shepherd, 2006). As a 2016 Wilton Park (a UK executive agency designed as a forum for discussion of global strategy) statement summarized, "research done in multiple regions suggests that those who are more devout are generally less likely to support violent extremism." ${ }^{23}$ More nuanced approaches that try to measure the impact of particular religious beliefs, such as support for religious influence over politics, similarly find inconsistent support (Fair et al., 2012). Additional research suggests, "The role of religion as a potential driver of violent extremism is significant, but religion usually interacts with a wide range of other factors" (Mandaville \& Nozell, 2017, 1). It also resonates with classic research in American public opinion suggesting the malleability of popular attitudes, particularly in response to elite cues that frame events in a compelling manner (Zaller, 1992).

Similar to this emphasis on elite framing, one productive move in recent scholarship on violence and religious beliefs has been a pivot to highlight the importance of what Thurston $(2020,8)$ calls the "meso-level" elites whose cues mobilize followers and build public support for violence. This approach suggests that, in the general public, the importance of religious beliefs ought to be contingent on other individual characteristics that render someone in the general public susceptible to the cues coming from violent entrepreneurs. This conclusion comes with implications for understanding the likely relationship between Christian Nationalism and the Capitol riot. While beliefs may make a contribution to support for extremist behavior, there is good reason to expect their effect to be contingent on elite inflammation of particular individual-level characteristics via cues. ${ }^{24}$ This is in keeping with Gorski and

19 Angel Rabasa, Cheryl Benard, Lowell Schwartz and Peter Sickle, "Building Moderate Muslim Networks," RAND Corporation, 2007, p. iii. Available at: https://www.rand.org/content/dam/rand/pubs/ monographs/2007/RAND_MG574.pdf

20 "Turning Point: A New Comprehensive Strategy for Countering Violent Extremism," Center or Strategic and International Studies, November 14, 2016. Available at: https://www.csis.org/features/turningpoint

21 "Department of State and USAID Joint Strategy on Countering Violent Extremism," May 2016, p. 3. Available at: https://2009-2017.state.gov/documents/organization/257913.pdf

22 "National Strategy for Counterterrorism of the United States of America," October 2018, p. 3. Available at: https://www.odni.gov/files/NCTC/documents/news_documents/NSCT.pdf

23 "Religion, radicalization and countering violent extremism," Wilton Park, April 29, 2016, p. 1. https:// www.wiltonpark.org.uk/wp-content/uploads/Statement-on-religion-radicalisation-and-countering-viole nt-extremism.pdf

24 While scholarship motivates our argument about elite cues, given our observational research design, we do not experimentally test the effect of such cue-giving. As we discuss in the conclusion, our findings here point to potential next steps using such experimental, cue-oriented research designs. 
Türkmen-Dervişoğlu's $(2013,194)$ dual challenge to avoid "subsuming" the content of religious beliefs and identities while also prioritizing "a fuller incorporation" of a "meso-level" of analysis, including elite attempts at stoking religious nationalism. Moving forward, we draw on existing research to highlight three candidate mechanisms likely to play this role, and thus strengthen the relationship between religious ideology and support for violence: perceived victimhood, reinforcing racial and religious identity, and immersion in conspiratorial information networks. ${ }^{25}$

\section{Religious Nationalism, Violence and Elite Cues: Victimhood, Racial Identity, and Conspiracism}

Our theory relies on both top-down and bottom-up factors to explain support for political violence. Some individuals believe the government ought to cater more to Christians but are unlikely to be moved to violence in the absence of elite-driven rhetoric urging mass action (indeed, this would more accurately describe "lone wolf" terrorist plots than mass action like that which occurred on January 6, 2021). Similarly, if political elites called for action in the streets, but feelings of Christian nationalism were not present, we doubt many would feel passionately enough to heed the call. Thus, both Christian nationalism and inflammatory elite discourse are necessary, but individually insufficient, ingredients for supporting mass violence. Indeed, research indicates that popular support for religious involvement in politics is far from uniform (Buckley, 2016; Djupe \& Calfano, 2014). We theorize that attention should fall on factors likely to be cued by elites that strengthen the tie between religious ideology and support for violence. In this light, we turn to three factors grounded in recent research: perceived victimhood, racial and religious identity, and conspiracism. Each relates to an intersection of threat perception and boundary drawing that has been shown to increase the effect of elite cues, including explicit calls for violence. We expect each to activate the link between Christian nationalism and violence via the effect of elite cues that highlight selective victimhood, waning power for certain identity groups, or nefarious plots perpetrated by other elites.

First, scholars have long pointed to the role of perceived victimhood in increasing support for political violence (Gurr 1970). Conceptually, victimhood may take many forms, such as an egocentric form where one internalizes feelings of victimhood or a systemic one that blames system-level forces (Armaly \& Enders, Forthcoming). In theorizing links between religious nationalism and support for violence, there is reason to suspect that victimhood, of either variant, would work in the same direction to strengthen that association. For example, systemic victimhood resonates with

\footnotetext{
${ }^{25}$ While these conditioning variables are grounded in recent scholarship, other candidates exist as well. In the American context, for instance, partisanship has become a key constraint on ideological politics, and may be linked to Christian nationalism's activation. The broader literature on support for political violence gives some pause on this point, however. Tessler and Robbins (2007) find that support for terrorism is strongest among those generally disaffected with existing political elites, rather than those with strong political allegiance, and Fair and Shepherd (2006) find those more supportive of statements characteristic of Islamist parties are less supportive of terrorism. See the conclusion for more discussion of the potential study of partisanship, Christian nationalism, and violence.
} 
extensive social psychological research on "chosen trauma" in the study of group identity, whereby "[participants] feel that [their] side is under personal attack and are compelled to defend their large group" (Volkan 2001, 87). Egocentric forms of victimhood have demonstrated similar ties, with Victoroff, Adelman et al. (2012) finding that experiences of individual discrimination correlate strongly with support for suicide bombing. Ginges (1997, 170) highlights the role of being "outside of, alienated from, society" in motivating terrorist behavior, while Knutson (1984, 293) similarly foregrounds "feelings of rage and hopelessness engendered by the belief that society permits no other access." Importantly, we describe victimhood that is perceptual in nature. No meaningful suppression of Christianity or the individual's life prospects needs to have occurred for individuals to feel like victims and bring those feelings to bear on their attitudes about the appropriate use of violence.

We not only expect higher levels of perceived victimhood to relate to support for violence, but also hypothesize that victimhood will enhance the links between Christian Nationalism and support for political violence because of its role in increasing receptiveness to elite cues. Scholars of religion and terrorist violence have repeatedly found that the perception of Islam being under threat correlates with increased support for terrorist elites claiming to represent Islam (Fair \& Shepherd, 2006, Bueno De Mesquita 2007, Obaidi, Kunst et al. 2018). Terrorist elites have demonstrated an awareness of this link between religion, perceived victimhood, and receptivity to their cues, flaunting prison experiences as a "credential" when attempting to build their audiences (Nielsen, 2017, 163). As Armaly and Enders (Forthcoming) show using an experimental design, feelings of victimhood can be inflamed visà-vis victim-cueing elite rhetoric from the likes of Donald Trump and Joe Biden. A combination of victim-cueing, partisan, and violent rhetoric-like that supplied by Trump during his "Save America" rally before the Capitol riot-is presumably capable of raising political tensions to a point that malignant attitudes translate into destructive behavior, at least for some. We expect that one who believes strongly that there should be increased congruence between Christian life and American governance and who also feels like a victim to be the most supportive of political violence. That is, we expect a conditional relationship, whereby higher levels of victimhood increase the effect of Christian nationalism on support for violence.

Second, we consider the role of white identity (Jardina 2019), which describes the centrality of whiteness to one's (racial) identity and the perceived connection between the fortunes of white Americans. White identity is powerfully associated with several racial grievances (Jardina 2019). A number of groups that espouse white supremacy, such as the Proud Boys, were prominent in the January 6 riots. In this instance, racial and religious identity would reinforce one another, which resonates with broader findings in the study of religion and political violence. There is a long history of attention to reinforcing cleavage structures leading to "unstable and weak" democracy (Lipset, 1959, 97) while cross-cutting ties raise the possibility of mitigating local political violence (Varshney, 2002). Cross-national statistical analysis from Selway (2011) demonstrates that reinforcing social identities operate distinctly from treating race, religion, or linguistic identity in isolation. Those strongly guided by racial and religious identities also view political and economic competition as zero-sum, and fear a future where they wield less political influence 
as non-whites gain more. Thus, it is sensible that those high in white identity would be more likely to support violence as a viable solution to uphold the status quo that maintains their group's social and economic influence.

We further hypothesize that white identity should strengthen the link between Christian nationalism and support for violence, because of white identity's susceptibility to inflammation vis-à-vis elite cues. Christian nationalism is overwhelmingly a white phenomenon and, as Baker et al. (2020) show, those high in Christian nationalism fear racial and ethnic "outsiders." Perry et al., (2020a, 2020b) demonstrate that Christian nationalism's effects are contingent on racial identification in certain scenarios, although they do not collect data allowing them to test the conditional role of the strength of racial identities. Experimental findings from Dunning and Harrison (2010) demonstrate the role of reinforcing social identities in conditioning the effect of elite cues, with cross-cutting identity cleavages undermining popular responsiveness to potentially divisive rhetoric. This is precisely the link between bottom-up identity and top-down cue-giving that grounds our expectations about the role of white identity in strengthening the link between Christian nationalism and violence. The reinforcing nature of religion and racial identity in fueling contemporary political violence may be best captured by Barkun (1997), who identifies the interweaving of Christianity and racial identity in the late-twentieth century "Christian identity" movement. All told, should an individual exhibit strong white identity, we expect a stronger link between Christian nationalism and support for political violence at the Capitol.

Finally, we expect that conspiratorial thinking--operationalized through support for the QAnon movement, in this context-should both increase support for violence in isolation and condition the strength of the relationship between Christian nationalism and support for political violence. Both conspiratorial thinking (Uscinski et al. Forthcoming), the general predisposition to interpret salient events and circumstances as the product of conspiracies, and support for the QAnon movement (Enders et al. ND) are related to support for political violence in general. Generally speaking, the more conspiratorial one is--the more likely they are to see nefarious individuals and groups as unfairly taking advantage of others or subverting norms and laws for their own selfish purposes--the more likely they will be to respond to (perceived) conspiratorial actions with similarly non-normative actions like violence. There is ample evidence linking religion and conspiracy in research in the American context (e.g., Barkun 1996, Oliver \& Wood, 2014). Vrzal (2020, 45) characterizes QAnon as "a variation of a Satanic conspiracy theory," and QAnon lore makes great use of millenarian Christian themes and imagery, such as final battle between good and evil called "the Storm" (akin to the battle tied to the Second Coming of Christ), from which "ten days of darkness" (similar to the "Three Days of Darkness" eschatological belief) would follow.

Because of the elite cues associated with conspiratorial information sources, we expect QAnon support to strengthen ties between Christian nationalism and support for political violence. The links between conspiratorial information sources and elite cues that blend religious and political content are well documented (Barkun 1996, Uscinski et al., 2016). While QAnon "lacks both a clear organizational structure and a centralization of interpretive duties," this does not mean that it lacks for 
elite-based cues (Amarasingam \& Argentino, 2020, 37). Cues from "less legitimate media" correlate with conspiracy belief (Stempel et al., 2007, 353), and experimental exposure to conspiratorial cues can "increase reported intentions to employ nonnormative, illegal means of political articulation" (Imhoff et al., 2021, 71). Cues from prominent Q-supporters were central to planning and carrying out the January 6th violence. Given the religious content and cues associated with such conspiratorial information sources, we expect that support for the QAnon movement would strengthen the relationship between Christian nationalism and political violence in the U.S.

In sum, we expect the relationship between Christian nationalism and support for political violence to be conditioned by individual characteristics that extant research shows can be manipulated by elite cues. Perceived victimhood, reinforcing racial and religious identity, and immersion in conspiratorial information sources should all strengthen the link between the beliefs associated with Christian nationalism and support for political violence like that seen in January 2021 at the U.S. Capitol. Again, this is consistent with both academic and policy work indicating that religious belief, in isolation, is an incomplete explanation of political violence. Rather, beliefs must be combined with other characteristics that elites can inflame to produce violence.

\section{Data and Measurement}

To test our theory, we used Lucid to field an original survey on 1100 U.S. adults in February 2021. While ours is not a probability sample, it is constructed such that it is largely representative of the U.S. adult population based on age, race, education, and sex; see the Online appendix for a comparison of these characteristics between our sample and the 2010 U.S. Census. Moreover, a recent investigation by Coppock and McClellan (2019) found that Lucid samples perform well in recovering political attitudes of the U.S. population. We undertook two additional steps to ensure the quality of our data. First, we required respondents to pass two attention checks; if they did not pass either one, they were not allowed to complete the survey. Second, we removed all respondents who sped through the survey; more specifically, if respondents spent less than $7 \mathrm{~min}^{26}$ on the survey, which was designed to take $15 \mathrm{~min}$, they were removed from the sample. After taking these steps and restricting our sample to white respondents only, ${ }^{27}$ the final sample size is 817 .

We employ two dependent variables. The first is participants' response, using a five-point scale ranging from "strongly disagree" (1) to "strongly agree" (5),

\footnotetext{
${ }^{26}$ Seven minutes is also the first quartile mark. While some survey organizations, like Qualtrics, only classify as speeders those with a completion time less than half the median, this number would be 4.6 min or less in our sample-much less time than necessary for completing some 90 survey questions. That said, results hold if we do not remove speeders from the sample.

27 To be clear, we do not argue that whites are exclusively prone to political violence or supportive of the Capitol attack. However, inclusion of a measure of white identity will inherently limit the sample to whites.
} 
to the following statement: "The riots at the U.S. Capitol building on January 6th were justified." The distribution of responses appears in panel A of Fig. 1. Approximately $14 \%$ of respondents "agree" or "strongly agree" that the Capitol riot was justified, $13 \%$ are neutral, and $72 \%$ "disagree" or "strongly" disagree. There is a weak correlation between this attitude and partisanship $(r=0.114$, $p=0.001)$, and the correlation with ideological self-identifications is not statistically significant $(r=0.047, p=0.210)$. As we might expect given both the immediate ("Save America" rally) and broader (2020 election) context of the Capitol riot, the correlation with support for Donald Trump--as assessed by a 101-point feeling thermometer--is much greater $(r=0.363, p<0.001)$.

Our second dependent variable is a summated scale of responses to the following three questions about support for political violence $(M=1.86, S D=1.09$, $\alpha=0.87$ ), each of which respondents reacted to using a five-point set of responses ranging from "strongly disagree" (1) to "strongly agree" (5): (1) It is acceptable to use violence in advancing political goals these days, (2) Violence is sometimes an acceptable way for Americans to express their disagreement with the government, and (3) Violence is justified if the members of the other side act violently first.

The distribution of the violence scale appears in panel B of Fig. 1. Approximately $13 \%$ of respondents agree more than they disagree with the use of political violence and $8 \%$ are completely neutral. As with the attitudes about the Capitol riot, the modal scale value is 1 , which corresponds with strong disagreement with each of the three statements; this characterizes $45 \%$ of respondents. These figures all comport nicely with those reported in other work on support for political violence that employ similar measurement strategies (Jolley \& Paterson, 2020; Kalmoe, 2014). The correlation between attitudes about the Capitol riot and the violence scale is $0.74(p<0.001)$.

We employ four central independent variables. Christian nationalism is measured via a summated scale of responses to six items developed by Whitehead et al., (2018a, 2018b). Respondents are asked to react, using five-point scales ranging from "strongly disagree" (1) to "strongly agree" (5), to statements such as "the federal government should declare the United States a Christian nation" and "the success of the United States is part of God's plan"; see the online appendix for all questions. The scale is statistically reliable $(M=3.05, S D=1.06, \alpha=0.86)$ and positively correlated with attitudes about the Capitol riot $(r=0.345, p<0.001)$ and the use of political violence $(r=0.239, p<0.001)$ more generally. We also find that Christian nationalism is significantly higher among evangelicals than other (non)religious groups $(p<0.05)$, and higher among conservatives and Republicans than Democrats, liberals, Independents, or moderates (all $p<0.05$ ). Additional details about who exhibits Christian nationalist beliefs appear in the Online supplemental appendix.

White identity is measured via a summated scale of responses to four items developed by Jardina (2019). Respondents are asked to react, using five-point scales ranging from "strongly disagree" (1) to "strongly agree" (5), to statements such as "it is important that whites work together to change laws that are unfair to whites" and "whites in this country have a lot in common with one another"; see the online appendix for all questions. The scale is statistically reliable $(M=3.28, S D=0.95$, 
$\alpha=0.81)$ and positively correlated with attitudes about the Capitol riot $(r=0.346$, $p<0.001)$ and the use of political violence $(r=0.298, p<0.001)$.

Our measure of perceived victimhood is adapted from Armaly and Enders (Forthcoming). Respondents are asked to react, using five-point scales ranging from "strongly disagree" (1) to "strongly agree" (5), to statements such as "the world is out to get me" and "I rarely get what I deserve in life"; see the online appendix for all questions. Whereas Armaly and Enders (Forthcoming) make a distinction between systemic and egocentric victimhood, we combine both variants of perceived victimhood into a single scale $(M=2.63, S D=0.96, \alpha=0.90)$, as we have no prediction about how either form should operate differently than the other when it comes to support for violence or Christian nationalism. And, indeed, all results presented below replicate using the two subscales, instead of the combination that we employ. Like Christian nationalism and white identity, perceived victimhood is positively correlated with attitudes about the Capitol riot $(r=0.358, p<0.001)$ and the use of political violence $(r=0.439, p<0.001)$.

Finally, we examine support for the QAnon movement. First, respondents are asked whether they have heard of QAnon; 64\% of white respondents report having heard of it. Such respondents are then asked, "Do you support the QAnon movement?" Approximately 13\% "support" or "strongly support" the QAnon movement (8\% of all whites, including those who have not heard of QAnon), 27\% are neutral (17\% of all whites), and $60 \%$ "oppose" or "strongly oppose" the movement $(39 \%$ of all whites). Support for the QAnon movement is more strongly correlated with support for the Capitol riot $(r=0.671, p<0.001)$ and the use of political violence $(r=0.637, p<0.001)$ than any of the other explanatory variables we consider. In the models accounting for QAnon support below, we only consider the $64 \%$ of white respondents who have heard of QAnon.

In addition to these variables, all multivariate models presented below control for partisanship, political ideology, income, education, age, gender, identification as Latinx, and residence in the political South. ${ }^{28}$ In order to decipher potential differences between Christian nationalism and religiosity more generally, we also control for affiliation with discrete religious denominations, as well as a measure of religious behavior based on the frequency of one's attendance of religious services (a five-point measure ranging from "never" to "every week") ${ }^{29}$ Details about question wording and coding for each of these variables appear in the appendix.

\footnotetext{
${ }^{28}$ In the appendix, we also present models that replicate those found below, also controlling for authoritarianism and perceptions of electoral fraud in 2020. Our results are robust to these additional controls.

29 It is important to note that we include these measures of alternative dimensions of religion as statistical controls, not in an attempt to falsify their potential role in building support for political violence. In practice, as shown in the appendix, several measures of religiosity are correlated with Christian nationalism. Thus, it would be misleading to interpret our results as demonstrating that factors like religious service attendance or white evangelical identification are unimportant in understanding support for the Capitol riots.
} 
A. Capitol Riot Justified

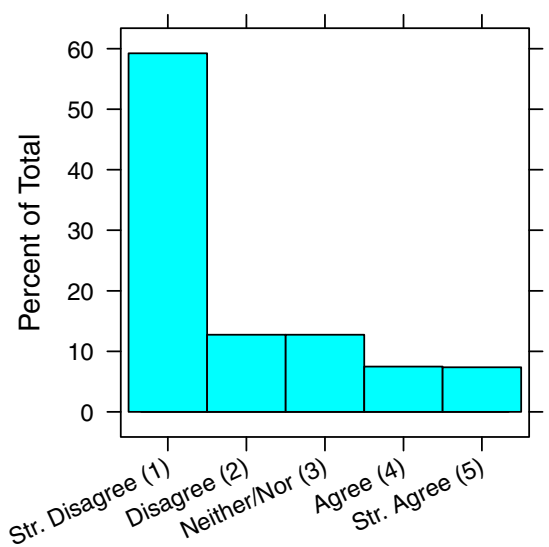

B. Support for Political Violence

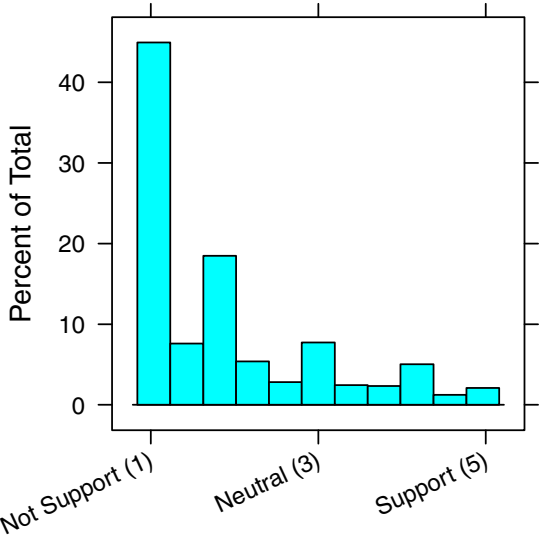

Fig. 1 Distribution of attitudes about the U.S. Capitol riots and political violence

\section{Empirical Analysis}

We have already established that each of our independent variables of interest is significantly positively correlated with support for the Capitol riot and political violence more generally. Next, we examine these relationships in the context of regression models, controlling for the other factors outlined above. We begin by specifying a series of three additive models for each of the two dependent variables. The first model includes controls plus measures of religious affiliation, such as evangelicalism, and religious behavior. ${ }^{30}$ This baseline model allows us to understand the relationship between support for political violence and both religious affiliation and behavior, as well as subsequently compare these relationships with that exhibited by Christian nationalism. Our expectation is that, while religious behavior may be a proxy for orientations like Christian nationalism in the baseline model, the effect should be greatly reduced with the inclusion of Christian nationalism. All models are estimated using ordinary least squares regression, ${ }^{31}$ and all independent variables have been rescaled to range from 0 (minimum value) to 1 (maximum value) to facilitate interpretation of the coefficients.

\footnotetext{
30 The primary models use unaffiliated individuals (i.e., agnostics, atheists, and those who report no religious affiliation) as the omitted reference category for evaluating the influence of religious identification. Results concerning Christian nationalism and interaction terms are not affected by use of alternative referent categories. We also note here that the evangelical dummy variable captures only Protestant evangelicals; alternative specifications that included non-Protestants who self-identify as evangelical did not impact results of interest.

31 Because of the skewed nature of the dependent variables, we also estimated the models using tobit regression, a model built for censored data. All results presented below hold. Estimates from these models appear in the appendix.
} 
In the baseline models ( 1 and 4), presented in Table 1 below, we find no relationship between any Christian religious category and support for violence, though we do observe positive, statistically significant relationships for religious behavior. In the second set of models ( 2 and 5 ), we build on the baseline models by including Christian nationalism, perceived victimhood, and white identity. In the third set of models (3 and 6), we additionally include support for QAnon. This variable was not included in the second set of models because the sample size is non-trivially attenuated by its inclusion--we lose respondents who have not heard of QAnon, approximately a third of the sample. Thus, while we include Christian nationalism, white identity, and perceived victimhood in the QAnon models, we also opted to present models that did not include support for QAnon.

First, we test the relationship in isolation between our independent variables of interest (Christian nationalism, victimhood, white identity, and conspiratorial beliefs) and support for political violence. Moving to models 2-3 and 5-6 in Table 1, we observe positive, significant relationships between both dependent variables and all independent variables of interest: Christian nationalism, perceived victimhood, white identity, and QAnon support. ${ }^{32}$

In order to better understand these relationships, we plot model-predicted attitudes about violence across the range of each independent variable of interest in Fig. 2. Christian nationalism, white identity, perceived victimhood and QAnon support all exhibit substantively similar relationships with attitudes about the Capitol riot. Individuals exhibiting the lowest levels of each of these characteristics fall somewhere between "strongly disagree" (1) and "disagree" (2), holding other variables constant. At the highest levels, individuals tend to fall somewhere between "disagree" (2) and "neither agree, nor disagree" (3). Relationships are slightly more variable when it comes to a more general support for political violence, though the same rough pattern emerges. Christian nationalism displays the weakest relationship of the four-perhaps the reason for the violence is more important for Christian nationalists than those who exhibit high levels of white identity, perceived victimhood, or support for the QAnon movement.

\section{Conditional Effects of Christian Nationalism}

Next, we specify interactive models whereby Christian nationalism is interacted with perceived victimhood, white identity, and QAnon support. ${ }^{33}$ Our theory holds

\footnotetext{
32 Models 1 and 4 (which do not contain measures of Christian nationalism or any of our hypothesized conditioning variables) do demonstrate a positive relationship between religious attendance and support for political violence, while religious tradition variables, compared to the unaffiliated baseline category, are not statistically significant. The statistical significance and magnitude of the estimated effect of religious attendance are substantially reduced in the fully specified models 3 and 6 . As we state in note 29, Christian nationalism is itself correlated both with certain religious affiliations and religious attendance, so we do not interpret these results as somehow ruling out the importance of studying links between those variables and support for political violence.

33 We also investigate these interactive relationships using cross-tabulation tables in the appendix; these simple analyses demonstrate the robustness of the conditional effects we model.
} 
that the strength of the relationship between Christian nationalism and support for violence--in the case of the Capitol riot and more abstractly--is conditional on the strength of one's identification with the white race, the extent to which one feels like a victim, and strength of QAnon support. Thus, all multiplicative terms across the interactive models-simplified versions of which appear in Table 2--should be positive.

We observe positive, statistically significant interactions between Christian nationalism and all theoretical conditional factors. To facilitate interpretation of these relationships, we plot the marginal effect of Christian nationalism on support for violence, conditional on perceived victimhood, white identity, and support for QAnon in Fig. 3. When it comes to both attitudes about violence, the marginal effect of Christian nationalism more than triples moving from the lowest to the highest levels of each of the conditional factors.

The results of these analyses prompt several conclusions. The Christian foundations of politically-motivated violence appear to lie in the interaction between a specific variant of Christian ideology, Christian nationalism, with other individual characteristics likely to increase exposure to elite cues. While Christian nationalism is strongly related to support for specific and abstract political violence on its own, it appears to be most potent when combined with other individual characteristics. Indeed, the combination of Christian nationalism with white identity, feelings of victimhood, and conspiratorial information sources may produce violent action, or at least support for it, where religious belief may not do so absent those other conditions. As Christian nationalism, perceived victimhood, and white identity are all positively correlated, this toxic blend strikes us as an empirical reality rather than a hypothetical. A similar warning note applies to other religious characteristics. While religious affiliation and attendance are not strong statistical predictors once Christian nationalism is included in multivariate analysis, several of those measures are highly correlated with Christian nationalist beliefs, indicating the interplay between religious nationalist belief and other dimensions of religiosity.

\section{Discussion and Implications}

The evidence we present is consistent with two conclusions. First, Christian nationalism in the United States is associated with increased support for political violence like that seen at the U.S. Capitol in January 2021. More broadly, however, religious ideology's effect on support for violence is essentially conditional. At low levels of white identity, perceived victimhood, and QAnon support, Christian nationalism was not a particularly influential predictor of support for violence. This suggests that attention to Christian nationalism should be contextualized rather than treated in isolation. Scholars of religion and political violence have generally moved to study religious ideology's conditional effect, and our findings suggest that such a move will be fruitful as the study of Christian nationalism develops beyond its incredibly successful initial stages.

The conditional nature of these effects should not be misunderstood to minimize the extent of the risks associated with Christian nationalism. While support for the 
Table 1 Additive OLS regressions of attitudes about the Capitol riot and general use of political violence

\begin{tabular}{|c|c|c|c|c|c|c|}
\hline & \multicolumn{3}{|c|}{ Capitol riot justified } & \multicolumn{3}{|c|}{ Support violence } \\
\hline & (1) & (2) & (3) & (4) & (5) & (6) \\
\hline Evangelical & $\begin{array}{l}0.169 \\
(0.161)\end{array}$ & $\begin{array}{l}-0.142 \\
(0.152)\end{array}$ & $\begin{array}{l}-0.051 \\
(0.165)\end{array}$ & $\begin{array}{l}0.091 \\
(0.133)\end{array}$ & $\begin{array}{l}-0.131 \\
(0.122)\end{array}$ & $\begin{array}{l}-0.103 \\
(0.137)\end{array}$ \\
\hline Protestant & $\begin{array}{l}-0.092 \\
(0.158)\end{array}$ & $\begin{array}{l}-0.253 \\
(0.145)\end{array}$ & $\begin{array}{l}-0.155 \\
(0.150)\end{array}$ & $\begin{array}{l}-0.119 \\
(0.131)\end{array}$ & $\begin{array}{l}-0.218 \\
(0.117)\end{array}$ & $\begin{array}{l}-0.180 \\
(0.125)\end{array}$ \\
\hline Catholic & $\begin{array}{l}0.123 \\
(0.144)\end{array}$ & $\begin{array}{l}-0.056 \\
(0.132)\end{array}$ & $\begin{array}{l}0.027 \\
(0.137)\end{array}$ & $\begin{array}{l}0.120 \\
(0.119)\end{array}$ & $\begin{array}{l}0.009 \\
(0.107)\end{array}$ & $\begin{array}{l}-0.015 \\
(0.114)\end{array}$ \\
\hline Other Christian & $\begin{array}{l}0.103 \\
(0.286)\end{array}$ & $\begin{array}{l}-0.335 \\
(0.256)\end{array}$ & $\begin{array}{l}-0.238 \\
(0.279)\end{array}$ & $\begin{array}{l}0.116 \\
(0.237)\end{array}$ & $\begin{array}{l}-0.243 \\
(0.207)\end{array}$ & $\begin{array}{l}-0.195 \\
(0.232)\end{array}$ \\
\hline Other Religion & $\begin{array}{l}0.200 \\
(0.152)\end{array}$ & $\begin{array}{l}0.015 \\
(0.137)\end{array}$ & $\begin{array}{l}-0.087 \\
(0.147)\end{array}$ & $\begin{array}{l}0.234 \\
(0.126)\end{array}$ & $\begin{array}{l}0.092 \\
(0.111)\end{array}$ & $\begin{array}{l}-0.046 \\
(0.123)\end{array}$ \\
\hline Religious Attendance & $\begin{array}{l}0.792^{* * *} \\
(0.140)\end{array}$ & $\begin{array}{l}0.362^{* *} \\
(0.131)\end{array}$ & $\begin{array}{l}0.069 \\
(0.145)\end{array}$ & $\begin{array}{l}0.458^{* * *} \\
(0.116)\end{array}$ & $\begin{array}{l}0.117 \\
(0.106)\end{array}$ & $\begin{array}{l}0.043 \\
(0.121)\end{array}$ \\
\hline Partisanship & $\begin{array}{l}0.449^{* *} \\
(0.153)\end{array}$ & $\begin{array}{l}0.275^{*} \\
(0.137)\end{array}$ & $\begin{array}{l}0.022 \\
(0.154)\end{array}$ & $\begin{array}{l}0.461^{* * *} \\
(0.127)\end{array}$ & $\begin{array}{l}0.327^{* *} \\
(0.111)\end{array}$ & $\begin{array}{l}0.145 \\
(0.128)\end{array}$ \\
\hline Ideology & $\begin{array}{l}-0.067 \\
(0.194)\end{array}$ & $\begin{array}{l}-0.254 \\
(0.177)\end{array}$ & $\begin{array}{l}-0.215 \\
(0.197)\end{array}$ & $\begin{array}{l}-0.522^{* *} \\
(0.160)\end{array}$ & $\begin{array}{l}-0.617^{* * * *} \\
(0.143)\end{array}$ & $\begin{array}{l}-0.595^{* * *} \\
(0.164)\end{array}$ \\
\hline Education & $\begin{array}{l}0.568^{* *} \\
(0.187)\end{array}$ & $\begin{array}{l}0.487^{* *} \\
(0.168)\end{array}$ & $\begin{array}{l}0.714^{* * * *} \\
(0.180)\end{array}$ & $\begin{array}{l}0.506^{* *} \\
(0.155)\end{array}$ & $\begin{array}{l}0.420^{* *} \\
(0.136)\end{array}$ & $\begin{array}{l}0.630^{* * * *} \\
(0.149)\end{array}$ \\
\hline Age & $\begin{array}{l}-1.519^{* * *} \\
(0.214)\end{array}$ & $\begin{array}{l}-1.523^{* * *} \\
(0.199)\end{array}$ & $\begin{array}{l}-0.418 \\
(0.236)\end{array}$ & $\begin{array}{l}-1.296^{* * *} \\
(0.178)\end{array}$ & $\begin{array}{l}-1.230^{* * *} \\
(0.161)\end{array}$ & $\begin{array}{l}-0.826^{* * *} \\
(0.196)\end{array}$ \\
\hline Latinx & $\begin{array}{l}-0.196 \\
(0.161)\end{array}$ & $\begin{array}{l}-0.088 \\
(0.143)\end{array}$ & $\begin{array}{l}-0.204 \\
(0.172)\end{array}$ & $\begin{array}{l}-0.074 \\
(0.133)\end{array}$ & $\begin{array}{l}0.020 \\
(0.116)\end{array}$ & $\begin{array}{l}-0.198 \\
(0.143)\end{array}$ \\
\hline Female & $\begin{array}{l}-0.374^{* * *} \\
(0.090)\end{array}$ & $\begin{array}{l}-0.163^{*} \\
(0.081)\end{array}$ & $\begin{array}{l}0.008 \\
(0.087)\end{array}$ & $\begin{array}{l}-0.487^{* * *} \\
(0.074)\end{array}$ & $\begin{array}{l}-0.292^{* * *} \\
(0.066)\end{array}$ & $\begin{array}{l}-0.167^{*} \\
(0.072)\end{array}$ \\
\hline South & $\begin{array}{l}-0.035 \\
(0.094)\end{array}$ & $\begin{array}{l}-0.067 \\
(0.084)\end{array}$ & $\begin{array}{l}0.014 \\
(0.090)\end{array}$ & $\begin{array}{l}-0.066 \\
(0.078)\end{array}$ & $\begin{array}{l}-0.085 \\
(0.068)\end{array}$ & $\begin{array}{l}-0.020 \\
(0.075)\end{array}$ \\
\hline Perceived Victimhood & & $\begin{array}{l}1.212^{* * *} \\
(0.175)\end{array}$ & $\begin{array}{l}0.755^{\text {**** }} \\
(0.190)\end{array}$ & & $\begin{array}{l}1.325^{* * *} \\
(0.141)\end{array}$ & $\begin{array}{l}0.746^{* * *} \\
(0.158)\end{array}$ \\
\hline White Identity & & $\begin{array}{l}1.332^{* * *} \\
(0.197)\end{array}$ & $\begin{array}{l}0.910^{* * *} \\
(0.220)\end{array}$ & & $\begin{array}{l}1.125^{* * *} \\
(0.159)\end{array}$ & $\begin{array}{l}0.787^{* * * *} \\
(0.183)\end{array}$ \\
\hline Christian Nationalism & & $\begin{array}{l}1.061^{* * *} \\
(0.217)\end{array}$ & $\begin{array}{l}0.492^{*} \\
(0.234)\end{array}$ & & $\begin{array}{l}0.721^{* * *} \\
(0.175)\end{array}$ & $\begin{array}{l}0.286 \\
(0.194)\end{array}$ \\
\hline Support Qanon & & & $\begin{array}{l}1.873^{* * *} \\
(0.178)\end{array}$ & & & $\begin{array}{l}1.370^{* * * *} \\
(0.148)\end{array}$ \\
\hline Constant & $\begin{array}{l}1.830^{* * *} \\
(0.198)\end{array}$ & $\begin{array}{l}0.489^{*} \\
(0.205)\end{array}$ & $\begin{array}{l}0.021 \\
(0.219)\end{array}$ & $\begin{array}{l}2.170^{* * *} \\
(0.165)\end{array}$ & $\begin{array}{l}0.901^{* * *} \\
(0.166)\end{array}$ & $\begin{array}{l}0.853^{* * *} \\
(0.182)\end{array}$ \\
\hline$R^{2}$ & 0.219 & 0.389 & 0.563 & 0.233 & 0.429 & 0.576 \\
\hline$n$ & 711 & 711 & 455 & 713 & 713 & 455 \\
\hline
\end{tabular}

OLS coefficients with standard errors in parentheses

$* p<0.05$

$* * p<0.01$

$* * * p<0.001$ 


\section{A. Capitol Riot Justified}

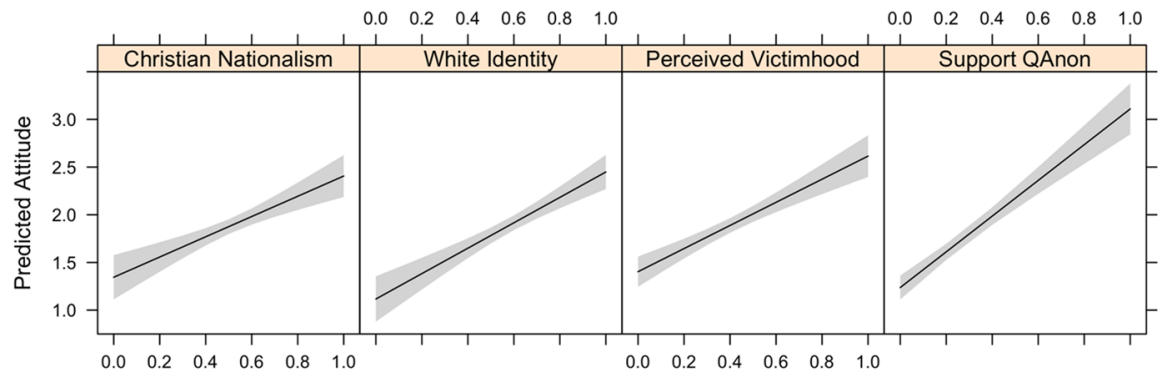

B. Acceptance of Violence

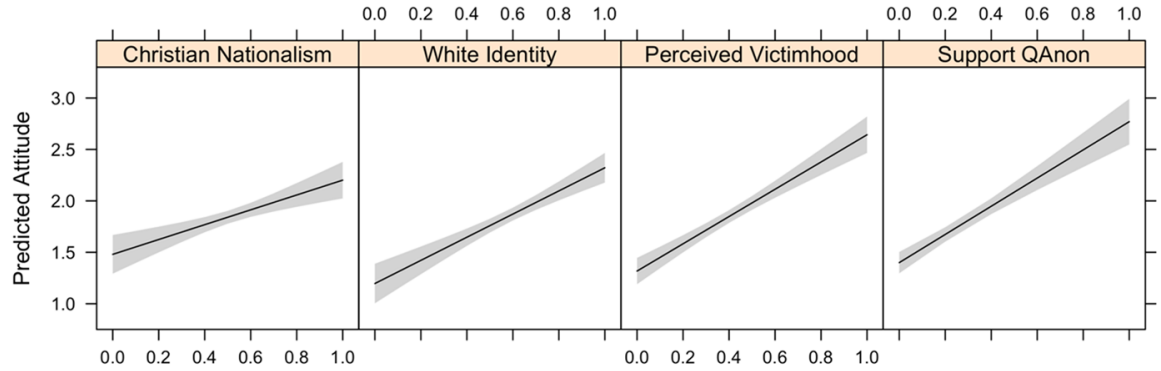

Fig. 2 Predicted attitudes about the Capitol riot and political violence across the range of each independent variable. Control variables held at their mean value. Shaded regions represent $95 \%$ confidence intervals

Capitol attacks is a minority position among any slice of the American religious landscape, the combination of characteristics most closely linked to support for violence occurs regularly. $6 \%$ of whites in our sample, $11.5 \%$ of white evangelicals, and $17.7 \%$ of white weekly church goers fall into the joint top quartile of justification of violence, Christian nationalist beliefs, perceived victimhood, white identity, and support for QAnon. 17.7\% of white Americans who regularly attend religious services would represent millions of individuals. It also represents a far greater share of the white American population than surveys find when testing Muslim-American support for terrorism. ${ }^{34}$

While this is not a piece of policy analysis, our findings do come with implications for governmental efforts to confront domestic extremism, which have received significant attention in the shadow of January 6. First and foremost, these efforts could repeat mistakes of earlier generations of policy designed to counter violent extremism, which tended to focus on religious ideology or beliefs in isolation. The results we present here suggest that efforts to promote "moderate" Christianity are likely to run into similar obstacles to twenty years of limited results from efforts to

\footnotetext{
${ }^{34}$ https://assets.pewresearch.org/wp-content/uploads/sites/11/2013/04/worlds-muslims-religion-politicssociety-selected-questions.pdf.
} 
Table 2 Interactive OLS regressions of attitudes about the Capitol riot and general use of political violence. See online appendix for full results

\begin{tabular}{llllll}
\hline & \multicolumn{2}{l}{ Capitol riot justified } & & \multicolumn{2}{l}{ Support violence } \\
\cline { 2 - 3 } \cline { 5 - 6 } & $(1)$ & $(2)$ & & $(3)$ & $(4)$ \\
\hline Perceived Victimhood & $-1.039^{* *}$ & $0.708^{* * *}$ & & -0.122 & $0.712^{* * *}$ \\
& $(0.366)$ & $(0.188)$ & & $(0.300)$ & $(0.157)$ \\
Christian Nationalism & $-1.157^{*}$ & 0.101 & & $-0.929^{*}$ & 0.002 \\
White Identity & $(0.449)$ & $(0.254)$ & & $(0.367)$ & $(0.212)$ \\
Support QAnon & 0.419 & $0.858^{* * *}$ & & 0.317 & $0.750^{* * *}$ \\
Victimhood $\times$ Nationalism & $(0.379)$ & $(0.218)$ & & $(0.310)$ & $(0.182)$ \\
White ID $\times$ Nationalism & & 0.560 & & 0.416 \\
QAnon $\times$ Nationalism & $4.032^{* * *}$ & $(0.400)$ & & $(0.334)$ \\
Constant & $(0.588)$ & & & $2.579^{* * *}$ & \\
& $1.421^{*}$ & & & $(0.481)$ & \\
$R^{2}$ & $(0.615)$ & & $1.325^{* *}$ & \\
$\mathrm{n}$ & & & & $(0.502)$ & \\
\hline
\end{tabular}

OLS coefficients with standard errors in parentheses

$* p<0.05$

${ }^{* *} p<0.01$

${ }^{* * * *} p<0.001$

promote "moderate" Islam or mobilize government resources to win a "war of ideas" within Islam. Instead, religion's impact on support for extremist violence is likely to be "interactive" (Mandaville \& Nozell, 2017, 1). In this case, for example, the strong conditioning effect of support for the QAnon movement suggests the urgent need for increased data collection on the explicit or implicit ways in which conspiratorial disinformation spreads through religious congregations and institutions. Moreover, as victimhood and white identity can be cued and strategically employed by political elites (Armaly and Enders Forthcoming; Jardina 2019), our results suggest attention to the types of messages from political and religious leaders intended to exacerbate the factors that condition the impact of Christian nationalism.

Our findings, drawn from one sample and an observational research design, also provide ample opportunities for further research. First, we theorize, but do not directly observe or test, that the factors enhancing Christian nationalism's effect on support for violence are tied to changing top-down mechanisms such as the supply of anti-establishment elite cues. Research has documented the ability of elite cues to stoke victimhood, white identity, and conspiracy beliefs, and Christian nationalism 


\section{A. Capitol Riot Justified}

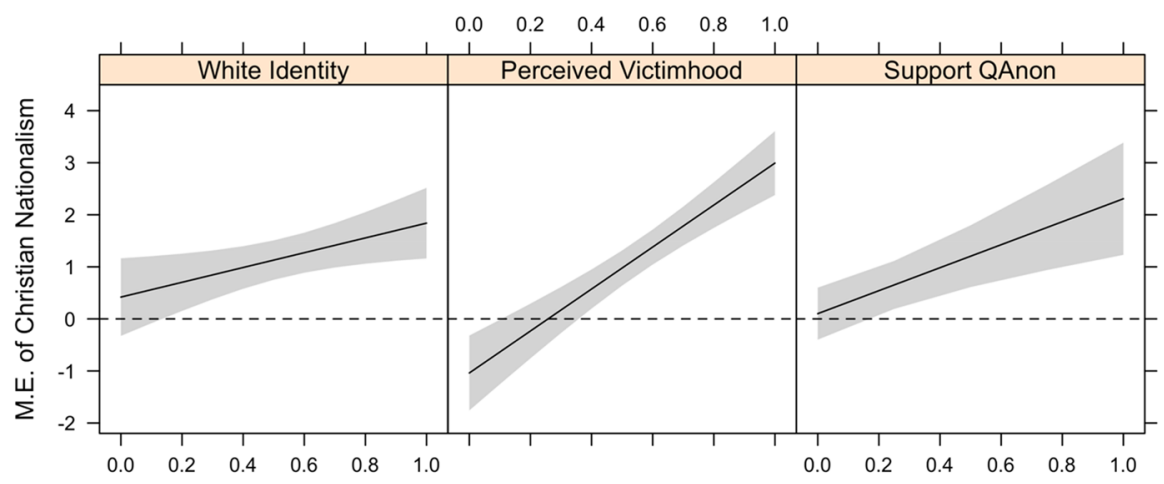

B. Acceptance of Violence

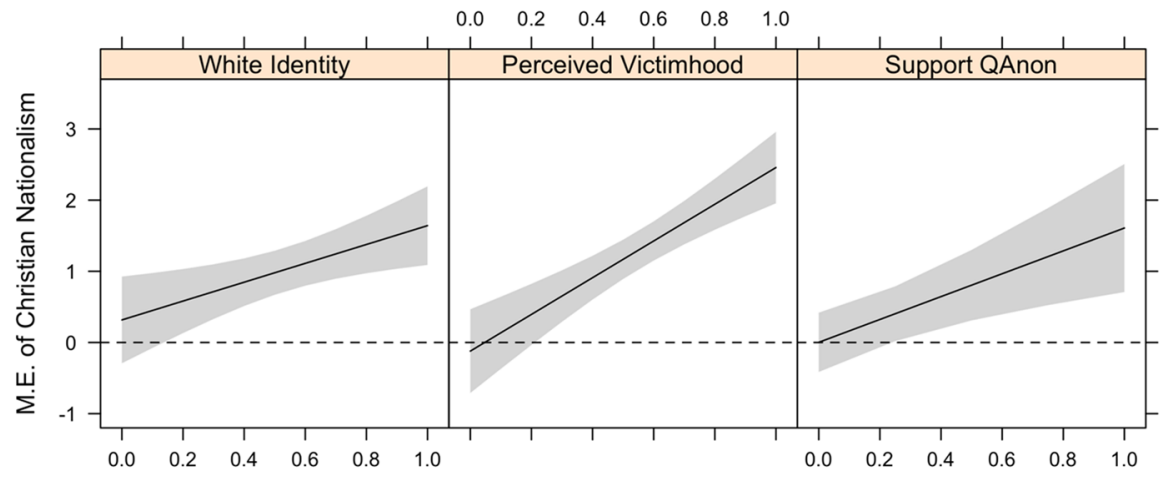

Fig. 3 Marginal effect of Christian nationalism on attitudes about the Capitol riot and political violence, conditional on perceived victimhood, white identity, and support for QAnon. Other independent variables held at their mean value. Shaded regions represent $95 \%$ confidence intervals

itself could well be manipulable in a similar way. Various experimental approaches could probe the mass-level effects of elite communication strategies. Building on recent experimental research (Buckley, 2020; Margolis, 2018), these designs could test which types of individuals are most responsive to Christian nationalist cues, and further investigate the reinforcing nature of cues that blend religious, racial, and even conspiratorial content. A significant body of recent research on clergy influence (Dujpe and Gilbert 2009), including attitudes related to tolerance (Djupe 2015), suggests that clergy influence may be substantial, but also contingent.

Second, these findings raise potentially productive questions about the interplay between Christian nationalism and partisanship. Previous work shows that conspiratorial thinking is not simply reducible to partisan affiliation or liberal-conservative ideology (Enders et al., 2020). And comparative research on terrorism has shown strong support for terrorism among those generally critical of existing political parties (Tessler \& Robbins, 2007). With that said, the events of January 6 were 
undeniably partisan in nature, with a closely contested election at their root. The Jericho March was founded not by established religious leaders, but individuals formerly nominated as Republican political appointees. Focusing on the linkages between elite cues and popular attitudes may present opportunities in this regard, for instance testing messenger effects when cues stoking violence are delivered by partisan sources as opposed to religious authorities.

Finally, our analysis focuses on links between Christian nationalism and one particular form of political behavior: support for contentious protest and political violence. This raises a broader set of questions regarding the interplay between Christian nationalism and political participation. There is an extensive literature focused on religion and political participation, generally focused on the role of religion in building social capital and positive associations with forms of civic involvement (Putnam, 2000; Son \& Wilson, 2012). QAnon supporters, however, participate in politics in a more unique and less normatively desirable way, engaging in interactive "research" about the nefarious activities of political elites and rallies to "save the children" from Satanic governmental pedophiles, for example. This raises the prospect of more detailed attention to how the particular set of beliefs conceptualized as Christian nationalism may relate to a broader set of institutional and extrainstitutional forms of civic participation and political behavior.

In each of these areas, the core findings about the powerful, conditional effects of Christian nationalism point to broad opportunities for further scholarship advancing our understanding of the interplay between religious ideology and political violence. The events of January 6, while seemingly unique in modern American politics, resonate with broader scholarship on violence, identity, victimhood, and conspiracy that point to likely future challenges to American democracy.

Supplementary Information The online version contains supplementary material available at https://doi. org/10.1007/s11109-021-09758-y.

Data Availability Replication files can be found at https://dataverse.harvard.edu/dataset.xhtml?persistent Id=doi:10.7910/DVN/0ZSTDM.

\section{References}

Amarasingam, A., \& Argentino, M. (2020). The QAnon conspiracy theory: a security threat in the making. CTC Sentinel, 13(7), 37-44.

Armaly, M.T. and A.M. Enders. Forthcoming. "Why Me?' The Role of Perceived Victimhood in American Politics.” Political Behavior.

Baker, J. O., Perry, S. L., \& Whitehead, A. L. (2020). Keep America Christian (and white): Christian nationalism, fear of ethnoracial outsiders, and intention to vote for Donald Trump in the 2020 presidential election. Sociology of Religion, 81(3), 272-293.

Barkun, M. (2017). President Trump and the "fringe." Terrorism and Political Violence, 29(3), 437-443.

Barkun, M. (1997). Religion and the racist right: The origins of the Christian Identity movement, UNC Press Books.

Bellah, R. N. (1992). The broken covenant : American civil religion in time of trial. University of Chicago Press.

Buckley, D. T. (2016). Demanding the divine? Explaining cross-national support for clerical control of politics. Comparative Political Studies, 49(3), 357-390. 
Buckley, D. T. (2020) Religious Elite Cues, Internal Division, and the Impact of Pope Francis' Laudato Si'. Politics and Religion: 1-33.

Bueno de Mesquita, E. (2007). Politics of suboptimal provision of counterterror. International Organization 61: 9-36.

Coppock, A., \& McClellan, O. A. (2019). Validating the Demographic. Political, Psychological, and Experimental Results Obtained from a New Source of Online Survey Respondents. https://doi.org/ $10.1177 / 2053168018822174$

Davis, J. T. and S. L. Perry (2020). "White Christian nationalism and relative political tolerance for racists." Social Problems.

Djupe, P. A. (2015). Religion and Political Tolerance in America: Advances in the State of the Art. Temple University Press.

Djupe, P. A., \& Calfano, B. (2014). God Talk : Experimenting with the Religious Causes of Public Opinion Temple University Press. https://doi.org/10.2307/j.ctvrf8960

Djupe, P. A. \& Gilbert, C. P. (2009). The political influence of churches. Cambridge University Press.

Dunning, T., \& Harrison, L. (2010). Cross-cutting cleavages and ethnic voting: an experimental study of cousinage in mali. The American Political Science Review, 104(1), 21-39.

Enders, A. M., Smallpage, S. M., \& Lupton, R. N. (2020). Are all "birthers" conspiracy theorists?: On the relationship between conspiratorial thinking and political orientations. British Journal of Political Science, 50(3), 849-866.

Enders, A. M., J. E. Uscinski, M. Seelig, C. Klofstad, J. Funchion, C. Everett, S. Wuchty, K. Premaratne, and M. Murthi. Forthcoming. "Who Believes in QAnon? A Case Study in Political Extremism." Journal of Politics. https://0c8c66a7-53e1-4b42-b593-cc8a0bb08b89.filesusr.com/ugd/524538_ b042fd60e4eb47a38b6dfc796564aebc.pdf

Fair, C. C., \& Shepherd, B. (2006). Who supports terrorism? Evidence from fourteen Muslim countries. Studies in Conflict \& Terrorism, 29(1), 51-74.

Fair, C. C., Malhotra, N., \& Shapiro, J. N. (2012). Faith or doctrine? Religion and support for political violence in Pakistan. Public Opinion Quarterly, 76(4), 688-720.

Fox, J. (2004). The rise of religious nationalism and conflict: ethnic conflict and revolutionary wars, 1945-2001. Journal of Peace Research, 41(6), 715-731.

Gorski, P. (2019). Why evangelicals voted for Trump: A critical cultural sociology (pp. 165-183). Springer.

Gorski, P. S., \& Covenant, A. (2017). A History of Civil Religion from the Puritans to the Present. Princeton University Press.

Gorski, P. S., \& Türkmen-Dervişoğlu, G. (2013). Religion, nationalism, and violence: an integrated approach. Annual Review of Sociology, 39, 193-210.

Grzymała-Busse, A. (2015). Nations under God: How Churches Use Moral Authority to Influence Policy. Princeton University Press.

Hoffman, B. (1993). "" H0ly Terror": The Implications (0f Terrorism M0tivated By A Religious Imperative."

Imhoff, R., Dieterle, L., \& Lamberty, P. (2021). Resolving the puzzle of conspiracy worldview and political activism: belief in secret plots decreases normative but increases nonnormative political engagement. Social Psychological and Personality Science, 12(1), 71-79.

Jacobs, C. M., \& Theiss-Morse, E. (2013). Belonging in a "Christian Nation": the explicit and implicit associations between religion and national group membership. Politics and Religion, 6(2), 373-401.

Jardina, A. (2019). White identity politics. Cambridge University Press.

Jolley, D., \& Paterson, J. L. (2020). Pylons Ablaze: examining the role of 5G COVID-19 conspiracy beliefs and support for violence. British Journal of Social Psychology, 59, 628-640.

Juergensmeyer, M. (2017). Terror in the mind of God: The global rise of religious violence, Univ of California Press.

Kalmoe, N. P. (2014). Fueling the fire: violent metaphors, trait aggression, and support for political violence. Political Communication, 31(4), 545-563.

Lewis, A. R. (2021). "Christian Nationalism and the Remaking of Religion and Politics, by Andrew L. Whitehead and Samuel L. Perry." Sociology of Religion.

Lipset, S. M. (1959). Some social requisites of democracy: economic development and political legitimacy. American Political Science Review, 53(1), 69-105.

Mandaville, P., \& Nozell, M. (2017). Engaging religion and religious actors in Countering Violent Extremism. DC, United States Institute of Peace. 
Margolis, M. F. (2018). How far does social group influence reach? Identities, elites, and immigration attitudes. The Journal of Politics, 80(3), 772-785.

McDaniel, E. (2011). Irfan Nooruddin, and Allyson Faith Shortle Divine Boundaries: How Religion Shapes Citizens' Attitudes toward Immigrants. American Politics Research, 39(1), 205-233.

Nielsen, Richard A. Deadly Clerics: Blocked Ambition and the Paths to Jihad. Cambridge University Press, 2017.

Obaidi, M., Kunst, J. R., Kteily, N., Thomsen, L., \& Sidanius, J. (2018). Living under threat: Mutual threat perception drives anti-Muslim and anti-Western hostility in the age of terrorism. European Journal of Social Psychology, 48(5), 567-584.

Oliver, E. J., \& Wood, T. (2014). Conspiracy theories and the paranoid Style(s) of mass opinion. American Journal of Political Science, 58(4), 952-966.

Perry, S. L., Whitehead, A. L., \& Davis, J. T. (2019). God's country in black and blue: How Christian nationalism shapes Americans' views about police (mis) treatment of blacks. Sociology of Race and Ethnicity, 5(1), 130-146.

Perry, S. L., Whitehead, A. L., \& Grubbs, J. B. (2020a). Culture wars and COVID-19 conduct: Christian nationalism, religiosity, and Americans' behavior during the coronavirus pandemic. Journal for the Scientific Study of Religion, 59(3), 405-416.

Perry, S. L., Whitehead, A. L., \& Grubbs, J. B. (2021b). The devil that you know: christian nationalism and intent to change one's voting behavior for or against trump in 2020. Politics and Religion. https://doi.org/10.1017/S175504832100002X

Putnam, R. D. (2000). Bowling alone : the collapse and revival of American community. New York, Simon \& Schuster.

Rapoport, D. C. (1984). "Fear and trembling: Terrorism in three religious traditions." The American Political Science Review: 658-677.

Selway, J. S. (2011). The measurement of cross-cutting cleavages and other multidimensional cleavage structures. Political Analysis, 19(1), 48-65.

Shortle, A. F., \& Gaddie, R. K. (2015). Religious Nationalism and Perceptions of Muslims and Islam. Politics and Religion, 8(3), 435-457.

Son, J., \& Wilson, J. (2012). Using Normative Theory to Explain the Effect of Religion and Education on Volunteering. Sociological Perspectives, 55(3), 473-499.

Soper, J Christopher, and Joel S Fetzer. Religion and Nationalism in Global Perspective. Cambridge University Press Cambridge, 2018.

Stempel, C., Hargrove, T., \& Stempel, G. H. (2007). Media Use, Social Structure, and Belief in 9/11 Conspiracy Theories. Journalism \& Mass Communication Quarterly, 84(2), 353-372.

Tessler, M., \& Robbins, M. D. H. (2007). What Leads some ordinary arab men and women to approve of terrorist acts against the united states?". Journal of Conflict Resolution, 51(2), 305-328.

Thurston, Alexander. Jihadists of North Africa and the Sahel: Local Politics and Rebel Groups. Cambridge University Press, 2020.

Uscinski, J. E., Klofstad, C., \& Atkinson, M. (2016). Why Do people believe in conspiracy theories? The role of informational cues and predispositions. Political Research Quarterly, 69(1), 57-71.

Uscinski, J. E., A. M. Enders, M. Seelig, C. Klofstad, J. Funchion, C. Everett, S. Wuchty, K. Premaratne and M. Murthi. Forthcoming. "American Politics in Two Dimensions: Partisan and Ideological Identities versus Anti-Establishment Orientations." American Journal of Political Science.

Varshney, A. (2002). Ethnic conflict and civic life: Hindus and Muslims in India. CT, Yale University Press.

Volkan, V. D. (2001). Transgenerational transmissions and chosen traumas: An aspect of large-group identity. Group Analysis, 34(1), 79-97.

Vrzal, Miroslav. "Qanon as a Variation of a Satanic Conspiracy Theory: An Overview." (2020).

Whitehead, A. L., \& Perry, S. L. (2015). A more perfect union? Christian nationalism and support for same-sex unions. Sociological Perspectives, 58(3), 422-440.

Whitehead, A. L., \& Perry, S. L. (2020). Taking America Back for God: Christian Nationalism in the United States. Oxford University Press.

Whitehead, A. L., Perry, S. L., \& Baker, J. O. (2018a). Make America Christian again: Christian nationalism and voting for Donald Trump in the 2016 presidential election. Sociology of Religion, 79(2), 147-171.

Whitehead, A. L., Schnabel, L., \& Perry, S. L. (2018b). Gun Control in the Crosshairs: Christian Nationalism and Opposition to Stricter Gun Laws. Socius, 4, 2378023118790189.

Zaller, J. (1992). The Nature and Origins of Mass Opinion. Cambridge University Press. 
Publisher's Note Springer Nature remains neutral with regard to jurisdictional claims in published maps and institutional affiliations. 